\title{
The Role of Self-esteem and Optimism in Job Satisfaction among Teachers of Private Universities in Bangladesh
}

\author{
Mozumdar Arifa Ahmed ${ }^{1}$ \\ ${ }^{1}$ Faculty of Business Administration, Eastern University, Bangladesh
}

\begin{abstract}
The objective of this study was to investigate the role of self-esteem and optimism in job satisfaction among teachers of private universities in Bangladesh. The measuring instruments used in this study were: 1. Self-Esteem Scale (SES) (Rosenberg's, 1965) for measuring self-esteem. 2. Life Orientation Test (LOT) (ScheierE Carver, 1985) for measuring Optimism. 3. Job Satisfaction Survey (JSS) (Spector, 1985) for measuring job satisfaction. According to the objective of the present study the obtain data were analysed using Pearson product moment correlation. The survey results revealed that self-esteem and optimism is significantly positively correlated with teacher's job satisfaction.
\end{abstract}

Keywords: Teaching, Teachers, Self-esteem, Optimism, Motivation, Job Satisfaction. JEL Classification Code: M12; M51

\section{INTRODUCTION}

$\mathrm{T}$ HE teacher can be rightly called a nation builder. Flourishing national development and a society truly prosperous with knowledge all begins from its teachers. Knowledge cannot be acquired if it is not sought and received through the help of the teacher. Teachers therefore, have to play a cardinal role in the building up of the character of the next generation. It is a fact that a civilization cannot rise out of a skeleton of mere ideas and abstract concepts. Civilization finds a concrete shape in the practical behaviour of a nation, based on these principles and concepts. This necessitates the provision of a learning atmosphere throbbing with life in our educational institutions through the presence of the teacher, with a view to infuse confidence in our students and to enable them to be proud of their culture, to respect their national character and national emblems, and to ornament themselves with societal conduct and morals. They should stand firm on the centuries old foundations of their cultural tradition and at the same time should establish standards of excellence in their academic performance. Because of this, teachers need to have a high level of commitment towards their duties and responsibilities. But now a days teaching profession is facing problems related toteachers' job satisfaction.

\section{Job satisfaction:}

The most widely accepted explanation of job satisfaction was presented by Locke (1976), who defined job satisfaction as "a pleasurable or positive emotional state resulting from the appraisal of one's job or job experiences" (p. 1304). Additionally, job satisfaction has emotional, cognitive and behavioral components. The emotional component refers to feelings regarding the job, such as boredom, anxiety, or excitement. The cognitive component of job satisfaction refers to beliefs regarding one's job, for example, feeling that one's job is mentally demanding and challenging. Finally, the behavioral component includes people's actions in relation to their work. These actions may include being tardy, staying late, or pretending to be ill in order to avoid work. Judge et al. (1997) considered self-esteem and optimism to be the most fundamental manifestation of core self-evaluation or positive self concept that was proposed as potential explanatory variables in the dispositional source of job satisfaction. They also argued that the construct should be related to work motivation and job performance.

\section{Self-esteem:}

Self-esteem represents the overall value that one places on oneself as a person. It reflects a person's overall evaluation or appraisal of his or her own worth. Self-esteem encompasses beliefs and emotions such as triumph, despair, pride and shame.Self-esteem can apply specifically to a particular dimension or have global extent. According to Maslow's need hierarchy theory of motivation, the esteem needs have two versions, a lower one and a higher one. The lower one is the need for the respect of others, the need for status, fame, glory, recognition, attention, reputation, appreciation, dignity, even dominance. The higher form involves theneed for self-respect, including such feelings as confidence, competence, achievement, mastery, independence, and freedom.

\section{Optimism:}

Optimism is as having hopefulness and confidence about the future or successful outcome of something; a tendency to take a favourable or hopeful view. It's a disposition or tendency to look on the more favourable sieof events or conditions and to expect the most favoura ble outcome. Some optimists consistently ascribe benevo- 
lent motives to others and interpret situations in the best possible light; others simply disassociate their internal mood from external circumstances. Optimists tend to use more problem- focused coping strategies than do pessimist. When problem- focused coping is not a possibility, optimists turn to more adaptive emotion- focused coping strategies such as acceptance, use of humour, and positive reframing of the situation. Pessimists tend to cope through overt denial and by mentally and behaviourally disengaging from the goals with which the stressor is interfering, regardless of whether something can be done to solve the problem or not. Optimists are people who tend to hold positive expectancies for their future; pessimists are people who tend to hold more negative expectations for the future.

\section{Theoretical Perspectives:}

Employee job satisfaction and motivation can be studied through several broad approaches content or need based theories, process theories and reinforcement theories. However, the term employee motivation is a complex and difficult term to define; therefore a precise definition of this concept is elusive as the notion comprises the characteristics of individual and situation as well as the perception of that situation by the individual (Ifinedo 2003; Rosenfeld \& Wilson 1999). An organization's liveliness, whether public or private, comes from the motivation of its employees, although their abilities play just as crucial a role in determining their work performance their motivation (Lewis, Goodman \&Fandt 1995).Golembiewski (1973, p. 597) refers to motivation as the degree of readiness of an organization to pursue some designated goal and implies the determination of the nature and locus of the forces inducing the degree of readiness. To Kelly (1974, p. 279), motivation has to do with the forces that maintain and alter the direction, quality and intensity of behaviour. According to Hoy and Miskel (1987, p. 176), employee motivation is the complex forces, drives, needs, tension states, or other mechanisms that start and maintain voluntary activity directed towards the achievement of personal goals. In short, Dessler (2001) defined motivation as the intensity of a person's desire to engage in some activity. From the above definitions some issues are brought to mind that deal with what starts and energizes human behavior, how those forces are directed and sustained as well as the outcomes they bring about (performance). It follows therefore that there is a relationship between motivation and job satisfaction. Peretomode (1991) citing Gibson, et al. pointed out that the two terms are related but are not synonymous. They acknowledged that job satisfaction is one part of the motivational process. While motivation is primarily concerned with goal-directed behavior, job satisfaction refers to the fulfillment acquired by experiencing various job activities and rewards.

\section{Need-based Approach or Content theory}

Several factors are believed to influence a person's desire to perform work or behave in a certain way. The need- based theories explained these desires; they explained motivation primarily as a phenomenon that occurs intrinsically, or within an individual. We can widely recognize two need-based theorists and their theories: Maslow's hierarchy of needs and Herzberg et al.'s two factor theory.

\section{Abraham Maslow's Hierarchy of Needs}

Abraham Maslow's (1943, 1970) need-based theory of motivation is the most widely recognized theory of motivation and perhaps the most referenced of the content theories. According to this theory, a person has five fundamental needs: physiological, security, affiliation, esteem, and self-actualization. The physiological needs include pay, food, shelter and clothing, good and comfortable work conditions etc. The security needs include the need for safety, fair treatment, protection against threats, job security etc. Affiliation needs include the needs of being loved, accepted, part of a group etc. whereas esteem needs include the need for recognition, respect, achievement, autonomy, independence etc. Finally, selfactualization needs, which are the highest in the level of Maslow's need theory, include realizing one's full potential or self development. According to Maslow, once a need is satisfied it is no longer a need. It ceases to motivate employees' behaviour and they are motivated by the need at the next level up the hierarchy.

However, in spite of Maslow's effort and insights into the theories of motivation, replicate studies failed to offer strong support of the need-based theories. Also, studies aimed at validating Maslow's theory failed to find substantiation in support of the needs hierarchy (Ifinedo 2003; Lawler \&Suttle 1972), although many continue to find the hierarchy model very attractive (Naylor, 1999).

\section{Herzberg et al.'s Two Factor Theory}

Herzberg, Mausner and Snyderman's (1959) two-factor theory is heavily based on need fulfilment because of their interest in how best to satisfy workers. They carried out several studies to explore those things that cause workers in white-collar jobs to be satisfied and dissatisfied. The outcome of their study showed that the factors that lead to job satisfaction when present are not the same factors that lead to dissatisfaction when absent. Thus, they saw job satisfaction and dissatisfaction as independent. They referred to those environmental factors that cause workers to be dissatisfied as Hygiene Factors. The presence of these factors according to Herzberg et al. does not cause satisfaction and consequently failed to increase performance of workers in white-collar jobs. The hygiene factors are company policy and administration, technical supervision, salary, interpersonal relationship with supervisors and work conditions; they are associated with job content. Herzberg et al. indicated that these factors are perceived as necessary but not sufficient conditions for the satisfaction of workers. They further identified motivating factors as those factors that make workers work harder. They posited that these factors are associated with job 
context or what people actually do in their work and classified them as follows: self respect, positive self concept, achievement, recognition, work itself, responsibility and advancement. Achievement is represented by the drive to excel, accomplish challenging tasks and achieve a standard of excellence. The individuals' need for advancement, growth, increased responsibility and work itself are said to be the motivating factors.

Herzberg et al., (1959) pointed out that the opposite of dissatisfaction is not satisfaction but no dissatisfaction. Both hygiene factors and motivators are important but in different ways (Naylor 1999: 542). Applying these concepts to education for example, if education improvement in universities depends, fundamentally, on the improvement of teaching, ways to increase teacher motivation and capabilities should be the core processes upon which efforts to make universities more effective focus. In addition, highly motivated and need satisfied teachers can create a good social, psychological and physical climate in the classroom. Exemplary teachers appear able to integrate professional knowledge (subject matter and pedagogy), interpersonal knowledge (human relationships), and intrapersonal knowledge (ethics and reflective capacity) when he or she is satisfied with the job (Collinson, 1996; Connell \& Ryan, 1984; Rosenholtz, 1989). Nonetheless, commitment to teaching and the workplace have been found to be enhanced by psychic rewards (acknowledgement of teaching competence), meaningful and varied work, task autonomy and participatory decision-making, positive feedback, collaboration, administrative support, reasonable work load, adequate resources and pay, and learning opportunities providing challenge and accomplishment (Firestone \&Pennel, 1993;Johnson, 1990;Rosenholtz, 1989). In contrast, extrinsic incentives, such as merit pay or effective teaching rewards have not been found to affect teacher job satisfaction and effectiveness. The extrinsic factors evolve from the working environment while the actual satisfiers are intrinsic and encourage a greater effectiveness by designing and developing teachers higher level needs. That is giving teachers greater opportunity, self respect, responsibility, authority and autonomy (Whawo, 1993).Conversely, Ukejeet al. (1992: 269) are of the opinion that however highly motivated to perform a teacher may be, he or she needs to posses the necessary ability to attain the expected level of performance. Nevertheless, it is hoped that if educational administrators and education policy makers can understand teachers' job satisfaction needs, they can design a reward system both to satisfy teachers and meet the educational goals.

\section{Process Theories}

The cognitive processes in determining employee level of motivation and need satisfaction. Equity theory matches the notions of "a fair day's work for a fair day's pay". It really focuses on perceptions of inequality in the output ratio whose effect may be similar to the hygiene factors of
Herzberg et al. (Naylor, 1999). Equity and fairness in the workplace has been found to be a major factor in determining employee motivation and job satisfaction (Lewis et al. 1995: 502). As such, equity theory assumes that one important cognitive process involves people looking around and observing what effort other people are putting into their work and what rewards follow that effort. This achievement, recognition, work itself, responsibility, advancement, company policy and administration, technical supervision, salary, interpersonal relationship with supervisor, work condition social comparison process is driven by our concern for fairness and equity. Research by McKenna (2000, p. 112) and Sweeney (1990) confirms equity theory as one of the most useful frameworks for understanding and has a role to play in the study of work motivation.

According to Lewis et al. (1995), expectancy theory is the most comprehensive motivational model that seeks to predict or explain task-related effort. The theory suggests that work motivation is determined by two factors: (1) the relationship between effort and performance and (2) the desirability of various work outcomes that are associated with different performance levels. Simply put, the theory suggests that the motivation that will lead to job satisfaction is a function of the perceived relationship between an individual's effort, performance, and the desirability of consequences associated with job performance (Lawler, 1973;Vroom, 1964). That is, employees are influenced by the expected outcomes of their behaviours and motivation at work or the perceptible link between effort and reward. The most important attribute of both types of process theory has been to draw attention to the effects of cognitive and perceptual processes on objective teachers' work conditions. It suggests that educational administrators and policy makers need to pay attention to the expectancy values that is the link between effort and teachers' needs satisfaction and job performance, determine what outcome teachers value, link the reward that teachers value to their job performance that teachers feel equity as well as satisfaction in their job.

\section{Reinforcement Theories}

Reinforcement theories relate to the idea of operant conditioning. They concentrate attention on the link between behaviour and consequences. Reinforcement is defined as any effect that causes behaviour to be repeated or inhibited which can be positive or negative (Naylor, 1999, p. 549). Skinner $(1939,1971)$ carried out several studies and came up with a conditioning model which proposes that if pleasant consequences follow behaviour, the behaviour will tend to continue whereas, if unpleasant consequences follow a behaviour, the behaviour tends to stop (Luthans\&Kreitner, 1985). This theory of motivation suggests that internal states of the mind such as needs are misleading, scientifically immeasurable, and in any case hypothetical. Therefore, reinforcement theory rests on two underlying assumptions: first, human behaviour is deter- 
mined by the environment, and second, human behaviour is subject to observable laws and can be predicted and changed. Hence, the foundation of the reinforcement theory is the 'law of effect', which states that behaviour will be repeated or not depending on whether the consequences are positive or negative (Lewis et al., 1995).

\section{RATIONALE OF THE STUDY:}

Teachers are important figure to develop a creative generation who will lead the country. Disgruntledteachers who are not satisfied with their job could not be committed and productive and would not beat the best of their capabilities. Now a days teaching profession is facing problems related toteachers' job satisfaction. The findings of the present study may help the institutions to reduce teachers' dissatisfaction by giving emphasis on providing intrinsic motivators, developing training program for increasing personal growth as well as self-worth of the teachers. It may also help the counsellors providing career counselling to the younger who are looking for their jobs to choose professions based on their personality traits.

\section{Research Questions:}

The present study gives rise to some question. Such as-

- Is there any relationship between self-esteem and job satisfaction among teachers of private universities in Bangladesh?

- Is there any relationship between optimism and job satisfaction among teachers of private universities in Bangladesh?

- What are the magnitudes of these relationships?

\section{Objectives OF the Study:}

The objectives of the present study are as follows-

- To investigate the relationship between self-esteem and job satisfaction among teachers of private universities in Bangladesh.

- To explore the relationship between optimism and job satisfaction among teachers of private universities in Bangladesh.

- To find out the magnitudes of the relationship between self-esteem and job satisfaction as well as optimism and job satisfaction.

\section{Methodology}

\section{Sample Selection}

The population of this research was the faculty members working in 51 private universities of Bangladesh. According to UGC (2008), there are 4,821 full-time faculty members working in these private universities. The research sample was selected from this population. The research sample was selected from these private universities. At first, the universities were divided into two clusters based on the establishment year. One cluster was consisted of the universities that were established within the year 1992 to 2001. The second cluster consists of the universities that were established from the year 2002 and onward. Then the Probability Proportionate to Sample (PPS) was applied on these two clusters. There were 15 universities in the first cluster and 28 universities in the second cluster. After applying PPS on the first cluster the selected universities were Ahsanullah Engineering and Technology University, University of Asia Pacific, and University of Development Alternative (UODA). From the second cluster the list of selected universities includes Stamford University, City University, Green University, Bangladesh University of Business and Technology (BUBT), University of Information Technology and Science (UITS), and ASA University. The ratio of the two clusters was 15:28. That's why, 3 universities were selected from the first cluster and 6 universities were selected from second cluster.

\section{Sample Size}

In these 9 universities, 1113 full-time faculty members were working. From these 9 universities a total number of 88 faculty members were selected based on the Simple Random Sampling technique. For identifying the sample size, confidence level was $95 \%$ and confidence interval was 10. According to the ratio for male and female faculty members in the selected private universities, $28 \%$ of the respondents were female. That means among 88 respondents, 25 were female.

\section{Data Collection Method}

To examine the research questions both primary and secondary data obtained from different sources.

\section{Primary Data}

The primary data was collected through structured questionnaire survey.

Measures used to collect primary data:

To measure the independent (Self-esteem and Optimism) and dependent variables (Job Satisfaction) the following measuring scales were used -

1. Self-Esteem Scale (SES) (Rosenberg's, 1965) for measuring self-esteem.

2. Life Orientation Test (LOT) (Scheier\& Carver, 1985) for measuring Optimism.

3. Job Satisfaction Survey (JSS) (Paul E. Spector, 1985) for measuring job satisfaction.

In addition a Demographic Information Blank was also used.

1. Self-Esteem Scale (SES)

Rosenberg's (1965) 10-item Self-Esteem Scale (SES) was used to assess self-esteem. The scale which provides a convenient measure of global attitudes about the self has five negatively worded items and five positively worded items. Participants were asked to indicate their agreement on a scale of 1 (strongly disagree) to 4 ( strongly agree) with statements such as "I feel I have a number of good qualities" and "At 
times, I think I am no good at all". This scale is one of the most widely used measures of self- esteem and has displayed good reliability and validity (Crandell, 1973; Rosenberg, 1965). In our sample, the scale had an internal reliability of .88 .

2. Life Orientation Test (LOT)

Optimism was measured by using the LOT (Scheier\&Carver, 1985). The LOT is an eight-item selfreport measure (plus four filler items) assessing generalized expectancies for positive versus negative outcomes. Respondents were asked to indicate their degree of agreement with statements such as "In uncertain times, I usually expect the best," and "I hardly ever expect things to go my way," using a 5point response scale ranging from 0 (strongly disagree) to 4 (strongly agree). Of the 8 scored items, 4 are worded in a positive direction and 4 are worded in a negative direction. After reversing the scoring for the negatively worded items, item scores were totalled to yield an overall optimism score with high scores representing greater optimism. In our sample, scores ranged from 0 to 32 Cronbach's alpha was 82 .

3. Job Satisfaction Survey (JSS)

Job satisfaction was measured by using The Job Satisfaction Survey, JSS (Spector, P.E., 1985)is a 36 item, nine facet scales to assess employee attitudes about the job and aspects of the job. Each facet is assessed with four items, and a total score is computed from all items. A summated rating scale format is used, with six choices per item ranging from "strongly disagree" to "strongly agree". Items are written in both directions, so about half must be reverse scored. The nine facets are Pay, Promotion, Supervision, Fringe Benefits, Contingent Rewards (performance based rewards), Operating Procedures (required rules and procedures), Co-workers, Nature of Work, and Communication.

\section{Secondary Data}

The secondary data was collected from different sources, such as academic articles, books, journals, earlier research reports and other published documents i.e. Annual Report of UGC.

\section{Result}

Pearson product moment correlation was used to determine the relationship between self esteem and job satisfaction as well as optimism and job satisfaction.

The relationship between self esteem and job satisfaction are shown in Table-1.

TABLE 1

CORRELATION OF SELF ESTEEM WITH JOB SATISFACTION:

\begin{tabular}{|l|c|c|}
\hline $\begin{array}{l}\text { Correlation of self } \\
\text { esteem with job } \\
\text { satisfaction }\end{array}$ & $\mathrm{r}$ & Significant level \\
\cline { 2 - 3 } & $.323^{*}$ & 0.05 \\
\hline
\end{tabular}

The table 1 indicated that self-esteem is significantly posi- tively correlated with job satisfaction $[\mathrm{r}=.323, \mathrm{p}<0.05]$. Thus, the teachers who had high self-esteem had high job satisfaction.

The relationship between optimism and job satisfaction is shown in Table-2.

TABLE 2

CORRELATION OF OPTIMISM WITH JOB SATISFACTION:

\begin{tabular}{|l|c|c|}
\hline $\begin{array}{l}\text { Correlation of } \\
\text { optimism with job } \\
\text { satisfaction }\end{array}$ & $\mathrm{r}$ & Significant level \\
\cline { 2 - 3 } & $373^{* *}$ & 0.01 \\
\hline
\end{tabular}

The table 2 indicated that optimism is significantly positively correlated with job satisfaction $[\mathrm{r}=.373, \mathrm{p}<0.01]$. Thus, the teachers who had high optimism had high job satisfaction.

The relation of self-esteem and optimism with the factors that are related with job satisfaction are shown in Table-3

TABLE 3

CORRELATION OF SELF-ESTEEM AND OPTIMISM BETWEEN THE FACTORS RELATED WITH JOB SATISFACTION:

The factors related Self-esteem Optimism with job satisfaction

\begin{tabular}{lcc}
\hline Pay & .213 & .106 \\
Promotion & $.477^{* *}$ & $.314^{*}$ \\
Supervision & -.056 & $.522^{* *}$ \\
Benefits & .256 & -.012 \\
Rewards & .132 & $.284^{*}$ \\
Operating proce- & -.264 & $-.515^{* *}$ \\
dures & & \\
Co-workers & .106 & $.302^{*}$ \\
Nature of work & $.283^{*}$ & $.500^{* *}$ \\
Communication & .214 & .188 \\
\hline${ }^{*} p<.05$, two-tailed ${ }^{* * p<.01, \text { two-tailed }}$ &
\end{tabular}

The table 3 indicated that self-esteem is significantly positively correlated with promotion and nature of work. On the other hand, optimism is significantly positively correlated with promotion, supervision, rewards, relationship with co-workers as well as nature of work and negatively correlated with operating procedure.

\section{Discussion}

Results of this study showed that self-esteem and optimism is significantly positively correlated with job satisfaction. The results mean that teachers who had high selfesteem had high job satisfaction. The result supports Judge, Locke and Durham's (1997)theory of core selfevaluations. Locke, McClear, and Knight (1996) noted, "A person with a high self-esteem will view a challenging job as a deserved opportunity which he can master and benefit from, whereas a person with low self-esteem is more likely to view it as an undeserved opportunity or a chance to fail" (p. 21). In fact, research suggests that individuals with high self-esteem maintain optimism in the 
face of failure, which makes future success (and thus future satisfaction) more likely (Dodgson \& Wood, 1998). Self-consistency theory (Korman, 1970) hypothesizes that individuals are motivated to behave in a manner consistent with their self-image. Thus, the theory predicts, individuals with high self-esteem will perform effectively in order to maintain their positive self-image. Theories of learned helplessness support a link between positive selfevaluations and job performance. According to the model of learned helplessness, when faced with unfavourable circumstances, individuals with a positive, optimistic explanatory style will be less likely to display motivational deficits (i.e., lower their effort, withdraw from task oriented behaviours), whereas those with a pessimistic explanatory style will display symptoms of helplessness (Peterson \& Seligman, 1984). Finally, control theory (Lord \&Hanges, 1987) predicts that when individuals perform below their expectations, they exert additional effort to obtain the performance goal, reduce their standard level (lower their aspirations), or withdraw from the task entirely. Research has shown that when individuals with an internal locus of control are faced with discrepancies between acceptable standards of performance and actual performance, they tend to increase their efforts to match their actual performance to the standards (Weiss \& Sherman, 1973). Conversely, people who have low selfesteem tend to either lower their standards or completely withdraw from the task when given negative feedback (Brockner, 1988).

Another result of this study showed that self-esteem is significantly positively correlated with promotion and nature of work. Another theoretical mechanism linking this result to job satisfaction is suggested by Korman's (1970) self consistency theory. Korman's theory predicts that individuals with high self-esteem choose occupations consistent with their interests, which would lead to greater levels of job satisfaction. More generally, Korman's theory predicts that high self-esteem individuals will engage in a broad array of behaviours and cognitions that reinforce their self concept. Positive self concept may help the person to perform well that leads to promotion. Peretomode (1991) and Whawo (1993), have suggested that the higher the prestige of the job, the greater the job satisfaction. In our society as a profession teaching is the noble and respectable job by nature of work. The person who had high self- esteem may have high preference of teaching for this task identity.

The result of the present study also shows that optimism is significantly positively correlated with promotion, supervision, rewards, relationship with co-workers and nature of work.The result support with the findings, Aspinwall and Taylor (1992) have shown that optimistic persons adjust more favourably to important life transitions than do persons who are more pessimistic in outlook. Another finding of the present study indicates that optimism is negatively correlated with operating procedure. Related research suggests that these differences in outcomes derive partly from differences between optimists and pessimists in the manner in which they cope with the challenges in their lives. Optimists differ from pessimists in their stable coping tendencies (Carver, Scheier\&Weintraub, 1989) and in the kinds of coping responses that they spontaneously generate when given hypothetical coping situations (Scheier, Weintraub, \& Carver, 1986). That's why optimist may cope better with difficult operating procedure and it make no sense to them to decrease job satisfaction. Thou they face difficult operating procedures; they have better satisfaction in job.

\section{CONCLUSION}

The present study indicates that studies on personality traits are necessary for understanding the underline patterns of individual issues of the teachers to increase job satisfaction. More research still required in this field to discover the relationship with lot more other factors. Some limitations like economical, time and manpower hindered this study in different ways such as - the study was conducted only in Dhaka, sample size was too small, scales for measuring were not in Bengali version etc. So the study recommends further research on larger sample from different areas of Bangladesh, that is proper representative sample and with better methodological sophistication.

\section{REFFERENCE}

[1] Aspinwall, L. G., \& Taylor, S. E. (1992) Modelling cognitive adaptation: A longitudinal investigation of the impact of individual differences and coping on college adjustment and performance. Journal of Personality and Social Psychology, 63, 989-1003

[2] Brockner, J. (1988) Self-esteem at work.Lexington, MA: Lexington Books.

[3] Carver, C. S., Scheier, M. F., \&Weintraub, J. K. (1989) Assessing coping strategies: A theoretically based approach. Journal of Personality and Social Psychology, 56, 267-283

[4] Collinson, V. (1996) Reaching Students: Teachers ways of knowing. Newbury Park, CA: Corwin Press.

[5] Golembiewski, R. T. (1973). Motivation. In Carl Heyel (Ed.), The Encyclopaedia of Management 2nd. New York: Van Nostrand Reinhold.

[6] Herzberg, F., Mausner, B. \&Snyderman, B.B. (1959) The Motivation of Works(2nd edition). New York: John Wiley and Sons.

[7] Hoy, W. K. \&Miskel, C. G. (1987). Educational Administration: Theory, Research and Practice.New York: Random House.

[8] Ifinedo, P. (2003). Employee Motivation and Job Satisfaction in Finnish Organizations: A Studyof Employees in the Oulu Region, Finland. Master of Business Administration Thesis, University of London

[9] Johnson, S. M. (1990). Teachers at work. New York: Basic Books.

[10] Judge, T. A., Locke, E. A., \& Durham, C. C. (1997) The dispositional causes of job satisfaction: A core evaluations approach. Research inOrganizationalBehavior, 19, 151-188.

[11] Kelly, J. (1974). Organizational Behavior. Homewood: Richard D. Irwin.

[12] Korman A. K.(1970) Toward an hypothesis of work behaviour. Journal of Applied Psychology, 54, 31-41. 
[13] Lawler, E. E. (1973). Motivation in Work Organization. New York: Brooks Cole.

[14] Lawler, E. \&Suttle, J. (1972). A Casual Correlation test of Need Hierarchy Concept.OrganizationalBehavior and Human Performance April, pp. 265-287.

[15] Lewis, P. S., Goodman, S. H. \&Fandt, P. M. (1995). Management: Challenges in the 21stCentury. New York: West Publishing Company.

[16] Locke, E. A. (1976) The nature and causes of job satisfaction. In M. D. Dunnette(Ed.), Handbookof industrial and organizational psychology. Chicago: Rand McNally

[17] Lord, R. G., \&Manges, P. J. (1987). A control systems model of organizational motivation: Theoretical development and applied implications. Behavioral Science, 32, 161-178.

[18] Locke, E. A., McClear, K., \& Knight, D. (1996). Self-esteem and work. International Review of Industrial/Organizational Psychology, 11, 132.

[19] Maslow, A. H. (1943). A theory of Human Motivation. Psychological Review, 50, p. 370

[20] Maslow, A. H. (1970). Motivation and Personality. 2nd edition, New York: Harper and Row.

[21] McKenna, E, F. (2000). Business Psychology and Organisational Behaviour: A Student'sHandbook. Hove: Psychology Press.

[22] Naylor, J. (1999). Management. Harlow: Prentice hall.

[23] Peretomode, V. F. (1991). Educational Administration: Applied Concepts and TheoreticalPerspective. Lagos: Joja Educational Research and Publishers.

[24] Peterson, C., \& Seligman, M. E. P. (1984). Causal explanations as a risk factor for depression: Theory and evidence. Psychological Review, 91, 347-374.

[25] Rosenberg, M. (1965) Society and the adolescent self image. Princeton, NJ: Princeton University Press.

[26] Rosenfelf, R. H. \& Wilson, D. C. (1999). Managing Organizations: Text, Readings and Cases,London: McGraw-Hill.

[27] Rosenholtz, S. (1989). Teachers' workplace: The social organization of schools. New York:Teachers College Press.

[28] Scheier, M. F., \& Carver, C. S. (1985) Optimism, coping and health: Assessment and implications of generalized outcome expectancies,
Health Psychology, 4, 219-247

[29] Scheier, M. F., Weintraub, J. K., \& Carver, C. S., (1989) Coping with stress: Divergent strategies of optimists and pessimists. Journal of Personality and Social Psychology, 51,1 257-1264

[30] Skinner, B. F. (1939). The Behavior of Organism: An Experimental Analysis. New York: D.Appleton-Central Company.

[31] Skinner, B. F. (1971). Beyond Freedom and Dignity. New York: Alfred Knopf

[32] Spector, P.E., (1985) Measurement of human service staff satisfaction: Development of the job satisfaction survey. American Journal of community Psychology, Vol. 13, No. 6, 1985, 693-713.

[33] Sweeney, P. D. (1990). Distributive justice and pay satisfaction: A field test of an equity theoryprediction. Journal of Business and Psychology, Vol. 4(3), 329-341

[34] Ukeje, B. O., Okorie, N. C. \&Nwagbara, U. A. (1992). Educational Administration: Theory andPractice. Abuja: Totan Publishers Ltd.

[35] Vroom, V. H. (1964). Work and motivation. New York: John Wiley \& Sons

[36] Whawo, D. D. (1993). Educational Administration: Planning and Supervision. Benin City:Jodah Publications.

[37] Weiss, H., \& Sherman, J. (1973). Internal-external control as a predictor of task effort and satisfaction subsequent to failure. Journal of AppliedPsychology, 57, 132-136.

[38] Connell, J. P. \& Ryan, R. M. (1984) A Developmental Theory of Motivation in the classroom. Teacher Education Quality, 11, pp. 64-77.

[39] Crandell, R. (1973) The measurement of self-esteem and related concepts. In J. P. Robinson and P. R. Shaver (Eds), Measures of social psychological attitudes (revised, pp 45-167) Ann Arbon University of Michigan Press.

[40] Dessler, G. (2001). Management: Leading People and Organization in the 21st Century. Harlow:Prentice Hall.

[41] Dodgson, P. G., \& Wood, J. V. (1998) Self-esteem and the cognitive accessibility of strengths and weaknesses after failure. Journal of Personality and Social Psychology, 75,178-197

[42] Firestone, W. A., \&Pennel, J. R. (1993) Teacher commitment, working conditions and differential incentive policies. Review of Educational Research, 63 (4), pp. 489-525 